4. Kitaya K, Takeuchi T, Mizuta S, Matsubayashi H, Ishikawa T. Endometritis: new time, new concepts. Fertil Steril 2018; 110: 344-50.

5. Kumar, A., \& Kumar, A. (2017). Hysteroscopic Markers in Chronic Endometritis. Journal of Minimally Invasive Gynecology, 24 (7), 10691070. doi: 10.1016 / j.jmig.2017.02.007

DOI https://doi.org/10.30525/978-9934-588-81-5-1.37

\title{
ПСИХОФІЗІОЛОГІЧНИЙ СТАН СПОРТСМЕНІВ-ІНВАЛІДІВ
}

\section{Луковська О. Л.}

кандидат медичних наук, старший науковий співробітник,

професор кафедри фізіології та спортивної медицини Придніпровська державна академія фізичної культури і спорту

Кудрявцева В. $\mathbf{C}$. кандидат біологічних наук, старший науковий співробітник, доцент кафедри фізіологї та спортивної медицини Придніпровська державна академія фізичної культури і спорту

\section{Бурдаєв К. В.}

кандидат наук з фізичного виховання і спорту, старший викладач кафедри фізіології та спортивної медицини Придніпровська державна академія фізичної культури і спорту

\section{Головачов М. М.}

викладач кафедри фізіологї та спортивної медицини Придніпровська державна академія фізичної культури і спорту

Мізін В. В.

викладач кафедри фізіології та спортивної медицини, Придніпровська державна академія фізичної культури і спорту м. Дніпро, Украӥна

Сучасні реалії спортивної практики, складність і напруження спортивної діяльності, які зростають вимагають всебічного врахування наукових, а також психологічних закономірностей у роботі зі спортсменами-інвалідами. У функціональній діагностиці психічного стану спортсменів-інвалідів важлива роль належить інформації, що отримується за допомогою різноманітних психологічних тестів, які дозволяють оцінювати функціональний стан психіки в цілому, ії готовність до тренувальних та змагальних навантажень. 
Оцінка стану психічної сфери спортсменів-інвалідів за матеріалами дослідження психологічних тестів розглядаються не ізольовано, а комплексно, спільно з психофізіологічними дослідженнями ЦНС.

У людей, які страждають патологією опорно-рухового апарату внаслідок перенесеного ДЦП та порушення слуху, достатньо часто спостерігається підвищення рівня агресії, тривожності, порушення самооцінки особи, втрата упевненості в собі, невротизація особи [1].

Прояви особистості динамічно змінюються під дією двох основних чинників: фізичного навантаження і стресу. Ці зміни носять складний характер і залежать від типу особи, її особливостей характеру і адаптивних здібностей [2].

Аналіз науково-методичної літератури показує, що тема психологічних досліджень психоемоційної сфери спортсменів-інвалідів є актуальною і ій присвячена значна кількість публікацій $[3,4]$.

Для оцінки психоемоційного стану особистості застосовували особистий опитувальник ЕРI (методика Г. Айзенка). 3 його допомогою можна визначити ступінь відвертості обстежуваного щодо навколишньому світу, його комунікабельність, ступінь невротизації, а також ступень щирості або нещирості при тестуванні. Використовували також опитувальник для психологічного тестування СпілбергаХаніна, який дозволяє визначити рівень ситуативної тривожності особи. Для самооцінки особистості також було застосовано опитувальник САН (самопочуття, активність, настрій).

При обстеженні спортсменів-інвалідів помітну роль грає визначення ступеня агресивності. Агресія може виражатися в прямій дії руйнування і насильства та в словесній формі. Використані тести шкали агресивності по Л.Б. Почебутом дозволяють 3 високою мірою наукової достовірності визначити рівні вербальної, фізичної, наочної, емоційної і самоагресії.

Для оцінки прихованих проявів особистості ми використовували проективний тест Люшера, що базується на експериментально встановленій залежності між перевагою, яку людина віддає певним кольорам (відтінкам) і його поточним психологічним станом свідомості та підсвідомості.

Соціальну фрустрацію визначали за методикою Вассермана. Соціальна фрустація розглядається як наслідок неможливості реалізації особою (здоровою або, тим більше, хворою) своїх актуальних соціальних потреб [5].

Дослідження проводилося в групі з 40 осіб, видами спорту. Вік обстежених був від 19 до 35 років. Серед обстежених спортсменів 18 осіб 
страждають порушеннями слуху та 22 - мають наслідки перенесеного ДЦП. Дослідження проводилося в предзмагальний період і під час учбово-тренувального збору.

При вивчені функціонального стану психічної сфери спортсменівінвалідів за опитувальником Айзенка встановлено, що екстравертивний тип особистості спостерігається у 85,00\% обстежених, тобто їх свідомість оріентирована на навколишній світ.

Інтравертивний тип особистості у обстежених виявлено у 5,0\%. Амбівалентний або середній тип зустрічається у $10 \%$ осіб, тобто їх свідомість може бути орієнтована як на особисті переживання, так і на зовнішній світ.

Нейротизм - цей показник характеризує ступінь невротизації особи. Високий рівень цього показника був у 52,5\% обстежених, середній у $37,5 \%$, а низький (норма) $-10,0 \%$.

Результати опитування за шкалою брехні теста Айзенка свідчать про те, що $65,0 \%$ респондентів проявляли щирість у відповідях тоді як $35,0 \%$ не дали вичерпні відповіді.

При вивчені функціонального стану психічної сфери спортсменівінвалідів затестами тривожності, самопочуття, активності та настрою i агресивності встановлено, що у 45,00\% досліджуваних інвалідів відзначався високий ступінь ситуативної тривожності, середній ступінь - у $42,5 \%$ і низький - тільки у $12,5 \%$. Ці показники свідчать про наявні порушення стану психічної сфери більшості обстежених осіб з обмеженими можливостями.

Тест САН показує, що незначна частина (10,0\%) досліджених дають завищену оцінку свого самопочуття, 70,0\% - оцінюють своє самопочуття як сприятливе чи нормальне та 20,0\% сприймають його як несприятливе.

Підвищена життєва активність має місце у 10,0\% обстежених, нормальний рівень активності присутній у 70,0\% спортсменів-інвалідів та знижена активність має місце у 20,0\%, що вказує на суб'єктивне відчуття перевтоми.

Підвищений настрій та настрій в межах норми спостерігався у значній більшості спортсменів-інвалідів (86,4\%), що свідчить про мотивованість спортсменів до занять спортивною діяльністю. Знижений настрій мав місце у $13,6 \%$ атлетів.

Оцінка показників агресії і психологічної адаптації показала, що висока ступінь агресії і низька адаптація спостерігаються у 52,5\% спортсменів-інвалідів, середній ступінь агресії і адаптації - у 32,5\% і лише $15,0 \%$ спортсменів мали низький ступінь агресії і високі адаптивні мо- 
жливості. Таким чином, великий відсоток спортсменів-інвалідів потребує додаткових заходів що до поліпшення їх адаптивних можливостей.

При дослідженні за тестом соціальної фрустрації встановлено, що спортсмени-інваліди мають достатньо високі показники рівня соціальної фрустрації, що до загального стану суспільства, але з тих питань, що стосується внутрішньо сімейних відносин та професійної діяльності, а також можливості занять спортом показник фрустрації є дуже низьким. Значний рівень фрустрації з загальносуспільних питань стосовно спортсменів-інвалідів та інвалідів взагалі потребує деяких змін до ставлення інвалідів у суспільстві. Але велика робота проведена в галузі фізичної культури та спорту, щодо можливості людей з фізичними завадами дає позитивні результати. Це свідчить, що досліджений контингент має достатньо сприятливі умови до занять спортом та вони за рахунок спортивної діяльності та сприятливих сімейних відносин успішно адаптуються до суспільного життя.

Показники результатів з основних кольорових диспозицій за тестом Люшера свідчать про наявність прихованого стресу у $100 \%$ обстежених, 54,54\% спортсменів вказують на несприятливу життєву ситуацію та 100\% знаходяться в прихованій депресії або схильні до неї.

Таким чином, проведене дослідження свідчить про негативний психоемоційний стан спортсменів-інвалідів, що потребує їх психологічної реабілітації.

\section{Література:}

1. Воронова В.І. Психологія спорту: Навчальний посібник / I: Олімпійська література, 2007. 298 с

2. Шуба В. Тревожность у паралимпийцев с поражением опорнодвигательного апарата. Спортивний вісник Придніпров'я. № 1. 2012. C. 207-211.

3. Луковська О., Петречук Л., Бурдаев К. Сучасні напрями фізичної реабілітації спортсменів-інвалідів 3 порушеннями опорнорухового апарату. Спортивний вісник Придніпров'я. 2016. № 2. C. 202-209.

4. Вассерман Л.И., Иовлев Б.В., Беребин М.А. Методика для психологической диагностики уровня социальной фрустированности иеё практическое применение. Методические рекомендации. НИПНИ им. Бехтерева, 2004. С. 20-25. 